\title{
ANALISIS GOOD MANUFACTURING PRACTICE (GMP) DAN MUTU DAGING RAJUNGAN PADA MINIPLANT PENGUPASAN DI KABUPATEN TUBAN
}

\author{
Jumiati, Muhammad Zainuddin \\ Prodi Ilmu Perikanan Fakultas Perikanan dan Kelautan Unirow Tuban, \\ email: astinmia@gmail.com, zaenmsdp@gmail.com
}

\begin{abstract}
ABSTRAK
Salah satu hasil perikanan yang mudah rusak/busuk atau bersifat perishable food adalah rajungan (Portunus pelagicus Linn). Terjadinya pembusukan setelah binatang tersebut mati akan berlangsung cepat jika penanganan pasca panen tidak dilakukan dengan baik. Aktivitas enzim dan bakteri merupakan penyebab utama penurunan mutu daging rajungan. Daya beli konsumen terhadap produk daging rajungan kalengan ditentukan oleh mutu daging rajungan sebagai bahan baku produk kalengan tersebut. Tujuan penelitian ini adalah mengkaji penerapan GMP (Good Manufacturing Practice) miniplant pengupasan rajungan dan mutu daging rajungan secara organoleptik (kenampakan, bau, cita rasa, dan tekstur daging) dan Mikrobiologis (TPC). Penelitian deskriptif dengan menggunakan metode survei melalui observasi, dan wawancara, Subyek penelitian adalah 7 miniplant pengupasan rajungan yang terdapat di Kabupaten Tuban. Analisa data dengan membandingkan kondisi hasil survey dengan pedoman GMP dan Analisis fisik yang dilakukan, meliputi uji organoleptik pada rajungan segar dan daging rajungan setelah pengupasan di mini plant Selain itu, uji. Analisis mikrobiologi dilakukan pada rajungan segar dan daging rajungan setelah pengupasan di miniplant pengupasan. Hasil penelitian menunjukkan bahwa mutu secara organoleptik daging rajungan segar dan matang adalah 8,6 dan 7,9. Nilai TPC daging rajungan segar sebesar 2,6 X $10^{4}$ sedangkan nilai TPC daging rajungan matang $3,7 \times 10^{5}$ Hasil penelitian penerapan GMP menunjukkan kesesuaian $\geq 70 \%$ pada alur proses pengupasan rajungan yaitu penerimaan bahan baku, sortasi, perebusan, dan penyimpanan, sedangkan pada alur proses pengupasan, pengecekan akhir, pengemasan, dan penyetoran ke pabrik pengalengan menunjukkan hasil kurang sesuai yaitu $\leq 70 \%$.
\end{abstract}

Kata kunci : Miniplant Pengupasan Rajungan, GMP, Organoleptik, Mikrobiologis

\begin{abstract}
One of the most perishable food products is the crab (Portunus pelagicus Linn).. The occurrence of decay after the animal died will take place quickly if post-harvest handling is not done well. Enzyme and bacterial activity is a major cause of deterioration in the quality of crab meat.The purchasing power of consumers towards canned crab meat products is determined by the quality of crab meat as raw material for canned products. The purpose of this study is to examine the implementation of GMP (Good Manufacturing Practice) miniplant stripping crab and the quality of organoleptic crab meat (appearance, smell, taste, and texture of meat) and Microbiological (TPC). Descriptive research using survey method through observation, and interview, Research subject is 7 miniplant stripping crabs found in Tuban. Data analysis by comparing condition of survey result with GMP guidance and Physical analysis conducted, including organoleptic test on fresh crabs and crab meat after stripping at mini plant In addition, test. Microbiological analysis was performed on fresh crabs and crab meat after stripping at stripping miniplant. The results showed that the organoleptic quality of fresh and ripe crab meat was 8.6 and 7.9. TPC value of fresh crab meat of $2.6 \times 10^{4}$ whereas TPC value of mature meat crab $3.7 \times 10^{5}$ The result of research of GMP application shows conformity of $\geq 70 \%$ in crushing stripping process that is acceptance of raw material, sorting, boiling, and storing, while in the stripping process, final checking, packaging, and depositing to cannery factory showed less suitable result that is $\leq 70 \%$.
\end{abstract}

Keywords: Miniplant Peeling of Rajungan, GMP, Organoleptik, Microbiological 


\section{PENDAHULUAN}

Komoditas perikanan yang saat ini banyak diminati di pasar internasional, salah satunya adalah rajungan (Portunus pelagicus Linn)(Sugeng dkk., 2003). Namun rajungan adalah hasil perikanan yang mudah mengalami pembusukan / rusak. Terjadinya pembusukan setelah binatang tersebut mati akan berlangsung cepat jika penanganan pasca panen tidak dilakukan dengan baik. Aktivitas enzim dan bakteri merupakan penyebab utama penurunan mutu daging rajungan. Daya beli konsumen terhadap produk daging rajungan kalengan ditentukan oleh mutu daging rajungan sebagai bahan baku produk kalengan tersebut. Perusahaan pengalengan biasanya menggunakan standar mutu rajungan yaitu rajungan dalam keadaan segar atau masih hidup, tidak terdapat bau asing (bau minyak tanah, solar, amonia, dan lain-lain), tidak kopong dan tidak dalam keadaan moulting, daging tidak dalam keadaan lunak ataupun hancur (Purwaningsih $d k k$. 2005).

Potensi hasil laut rajungan yang cukup besar di Kabupaten Tuban belum diimbangi oleh pengusaha perikanan bidang rajungan di Kabupaten Tuban dengan memiliki persyaratan dasar cara 20 memproduksi hasil perikanan yang baik dan benar, dan sebagian besar hanya untuk memenuhi bahan baku pabrik pengalengan rajungan. Hasil tangkapan rajungan di Kabupaten Tuban berdasarkan data dari Dinas Perikanan dan Kelautan Kabupaten Tuban (2015) antara tahun 2008 - 2014 seperti Tabel 1 berikut :

Tabel 1. Data Hasil Tangkapan Rajungan di Kabupaten Tuban

\begin{tabular}{ccc}
\hline Tahun & $\begin{array}{c}\text { Volume } \\
\text { (Ton) }\end{array}$ & $\begin{array}{c}\text { Nilai Produksi } \\
\text { (jutaan rupiah) }\end{array}$ \\
\hline 2008 & 226,07 & $4.891,02$ \\
2009 & 251,22 & $5.592,872$ \\
2010 & 239,3 & $5.704,55$ \\
2011 & 157,67 & $4.466,75$ \\
2012 & 25,32 & 982,59 \\
2013 & 26,59 & $1.128,43$ \\
2014 & 27,18 & $1.155,55$ \\
\hline
\end{tabular}

Berdasarkan data pada tabel 1 menunjukkan terjadinya penurunan jumlah hasil tangkapan rajungan. Penurunan dalam jumlah ekspor rajungan mayoritas disebabkan turunnya hasil tangkapan nelayan karena pengaruh cuaca yang kurang baik sehingga nelayan hanya melakukan penangkapan ikan di laut dangkal. Dengan semakin ketatnya persyaratan mutu eksport hasil perikanan, terutama produk rajungan untuk Jepang, Amerika Serikat dan Uni Eropa, agar eksport rajungan Indonesia tetap eksis, maka mutu produk rajungan yang lebih 
baik dari beberapa negara pesaing merupakan hal yang mutlak. Selama ini daging rajungan yang diolah di unit pengolahan ikan sebagai bahan baku pengalengan masih mengalami penolakan pada saat disortir di pabrik pengalengan rajungan sebelum diproses selanjutnya sebagai produk pasteurize crab meat. Diperlukan manajemen mutu yang baik pada bahan baku rajungan segar dari nelayan dan daging rajungan kupas yang diolah dari miniplantminiplant untuk mencapai mutu produk rajungan yang sesuai standar mutu pengalengan. Sehingga mutu bahan baku daging rajungan yang akan disetor ke perusahaan pengolah rajungan akan lebih baik dan para pemasok daging rajungan akan tetap survive dalam usahanya.

Standar mutu mutlak diterapkan untuk menjamin mutu dan keamanan pangan yang sesuai dengan tuntutan konsumen. Hal ini sejalan dengan adanya tuntutan ekivalensi sistem pembinaan dan pengawasan mutu hasil perikanan yang diterapkan di Indonesia yang ditujukan untuk melindungi konsumen. Proses pengolahan daging rajungan untuk kebutuhan bahan baku terutama untuk pasteurize crab meat memerlukan bahan baku daging rajungan yang berkualitas prima, namun masih terdapat daging rajungan yang ditolak pada saat penyortiran oleh perusahaan pengalengan (Satumalay, 2012).

Untuk mengetahui mengenai penerapan standart mutu yang dilaksanakan oleh miniplant rajungan dalam memenuhi standart mutu perusahaan pengalengan, maka penelitian ini perlu dilakukan. Permasalahan yang perlu dijawab pada miniplant sebagai pengupas rajungan yang terdapat di Kabupaten Tuban adalah : 1) Apakah miniplant sudah melakukan penerapan GMP (Good Manufacturing Practice) sesuai pedoman GMP (Good Manufacturing Practice)? dan 2) Apakah mutu daging rajungan di miniplant sudah sesuai pedoman SNI 4224:2015 ?. Tujuan Penelitian ini adalah mengkaji penerapan GMP (Good Manufacturing Practice) dan mutu daging (organoleptik dan mikrobiologis) pada miniplant pengupasan rajungan di Kabupaten Tuban.

\section{METODE PENELITIAN}

Metode Penelitian deskriptif, menggunakan metode survei dalam pengumpulan data melalui observasi dan wawancara, Subyek penelitian adalah 7 miniplant rajungan yang terdapat di Kabupaten Tuban. Aspek penilaian berdasarkan Pedoman Penilaian Kelayakan Dasar Unit Pengolahan Ikan (Departemen Kelautan dan Perikanan. 
2007), Pedoman GMP PT Mina Global Mandiri (Priyanti. 2007) dan Pedoman GMP untuk miniplant dari PT Tiur Tonga Putra. Pedoman GMP (Good Manufacturing Practice) sesuai alur proses pengupasan rajungan meliputi :

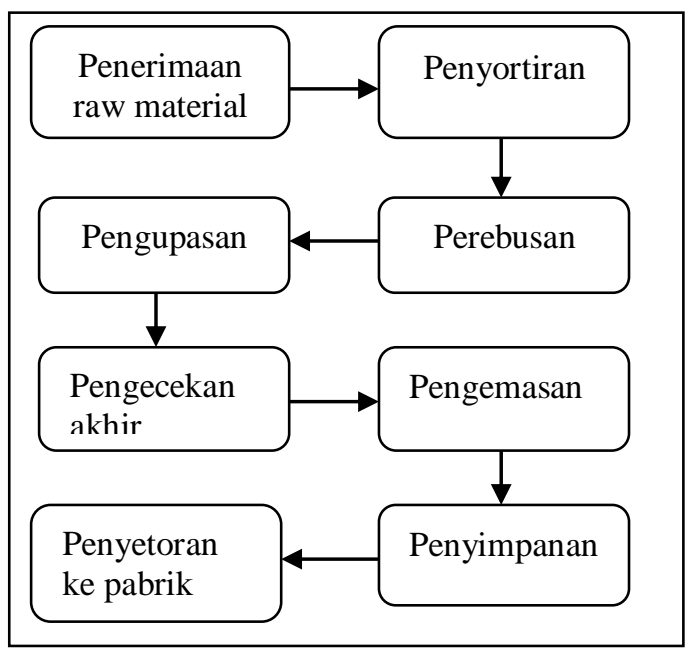

Gambar 1. Alur Proses Pengupasan Rajungan

\section{Analisis}

Analisis sampel yang diiakukan pada penelitian ini meliputi analisis fisik dan analisis mikrobiologi. Analisis fisik yang dilakukan, meliputi uji organoleptik pada rajungan segar dan daging rajungan setelah pengolahan di mini plant Selain itu, uji. Analisis mikrobiologi dilakukan pada rajungan segar dan daging rajungan setelah pengupasan di mini plant pengupasan rajungan.

\section{HASIL DAN PEMBAHASAN}

\section{Profil Miniplant Subyek Penelitian}

Tabel 2. Data Miniplant Penelitian

\begin{tabular}{llll}
\hline $\begin{array}{c}\text { Pemilik } \\
\text { Miniplant }\end{array}$ & $\begin{array}{c}\text { Bahan } \\
\text { Baku }\end{array}$ & $\begin{array}{c}\text { Setor } \\
\text { Pabrik }\end{array}$ & $\begin{array}{c}\text { Tenaga } \\
\text { Kerja }\end{array}$ \\
\hline SUPARDI & 1 ton & $\pm 1 \mathrm{kw}$ & $15 \mathrm{org}$ \\
DANI & $2 \mathrm{kw}$ & $50 \mathrm{~kg}$ & $13 \mathrm{org}$
\end{tabular}

\begin{tabular}{llll} 
WALISONGO & $1 \mathrm{ton}$ & $1 \mathrm{kw}$ & 14 org \\
PUTRA GALUH & $3 \mathrm{kw}$ & $75 \mathrm{~kg}$ & 20 org \\
MUNITO & $3 \mathrm{kw}$ & $75 \mathrm{~kg}$ & 20 org \\
UD BAROKAH & $4 \mathrm{kw}$ & $1 \mathrm{kw}$ & 22 org \\
RUDI & $5 \mathrm{kw}$ & $125 \mathrm{~kg}$ & 15 org \\
\hline
\end{tabular}

Berdasarkan data pada tabel di atas menunjukkan, miniplant yang terbanyak pada Desa Kradenan, karena di desa tersebut mayoritas warga bermata pencaharian sebagai nelayan yang menggunakan alat tangkap perangkap (bubu) untuk menangkap rajungan. Pemilik miniplant adalah pemasok daging rajungan hasil pengupasan yang disetorkan ke pabrik pengalengan daging rajungan. Bahan baku adalah rajungan segar yang diperoleh dari hasil melaut nelayan, apabila hasil rajungan melimpah saat musimnya, pemilik miniplant biasanya menyetorkan sebagian dalam bentuk rajungan rebus pada pabrik dikarenakan jumlah tenaga pengupas yang kurang memadai. Pembayaran tenaga pengupas dengan sistem borongan, berkisar antara Rp. 12.000,- sampai dengan Rp. 25.000,- per kg daging rajungan kupas. Beberapa pabrik pengalengan sebagai tujuan penyetoran dari miniplant adalah PT Kelola Mina Laut, PT Tiur Tonga Putra (sekarang menjadi PT Sumber Mina Bahari), PT Indomanis.

Hasil daging pengupasan rajungan (rendemen) sekitar 25\% dari berat badan rajungan segar. Berdasarkan hasil penelitian dari Widhiastuti (2010), 
rendemen daging rajungan normalnya adalah berkisar antara 25-30\%. Tinggi rendahnya rendemen daging ditentukan dari keahlian tenaga pengupas dalam mengupas cangkang dan proses pemasakan yang benar.

\section{GMP (Good Manufacturing Practice)}

Hasil penilaian penerapan GMP dari 7 miniplant, menunjukkan nilai ratarata yaitu pada alur proses : penerimaan bahan baku menunjukkan nilai 100\% sesuai. Sortasi bahan baku menunjukkan nilai $76 \%$ sesuai dan $24 \%$ kurang sesuai. Perebusan menunjukkan nilai $71.4 \%$ sesuai dan $28.6 \%$ kurang sesuai. Pengupasan menunjukkan nilai $44,4 \%$ sesuai, 54\% kurang sesuai dan 1,6\% tidak sesuai. Pengecekan Akhir menunjukkan nilai 50\% sesuai dan $50 \%$ kurang sesuai. Pengemasan menunjukkan nilai $33.3 \%$ sesuai dan $66.7 \%$ kurang sesuai. Penyimpanan menunjukkan nilai $72 \%$ sesuai dan $28 \%$ kurang sesuai. Penyetoran ke pabrik menunjukkan nilai $50 \%$ sesuai dan $50 \%$ kurang sesuai.

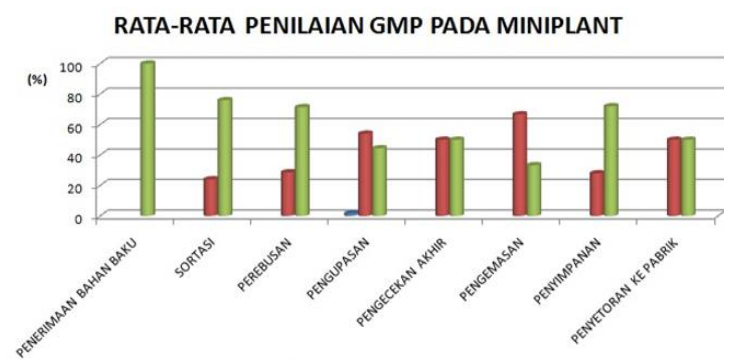

Gambar 2. Penilaian GMP pada 7 Miniplant
Hasil penelitian penerapan GMP pada Gambar 4 menunjukkan kesesuaian $\geqq 70 \%$ pada alur proses pengupasan rajungan yaitu penerimaan bahan baku, sortasi, perebusan, dan penyimpanan, sedangkan pada alur proses pengupasan, pengecekan akhir, pengemasan, dan penyetoran ke pabrik pengalengan menunjukkan hasil kurang sesuai yaitu $\leq$ $70 \%$.

Penerimaan bahan baku rajungan segar diperoleh langsung dari hasil melaut, sortasi dilakukan pemilihan ukuran maupun jenis rajungan untuk menentukan harga beli dari nelayan. serta secara organoleptik dengan melihat bentuk fisik rajungan untuk menentukan segar dan tidaknya. Perebusan dilakukan langsung setelah penimbangan, tidak lebih dari 30 menit jarak waktu dari penerimaan, waktu perebusan $30-45$ menit dengan suhu $100 \quad{ }^{\circ} \mathrm{C} \quad-200^{\circ} \mathrm{C}$. Penyimpanan dilakukan setelah daging dikemas dalam toples dan dimasukkan dalam box dengan ditimbun es yang dicurai.

Pengupasan dilakukan dengan memisahkan bagian tubuh rajungan yaitu kaki, supit, dan badan untuk dikupas sesuai jenisnya yaitu : jumbo, flower, special, backfin, clawmeat, dan merus. Selama pengupasan ada beberapa prosedur yang tidak sesuai antara lain, rajungan yang dikupas ada yang sisa 
sehari sebelumnya berupa rajungan beku, sehingga tidak dalam kondisi fresh. Pengecekan akhir dilakukan sebelum ditimbang untuk mengetahui adanya sisa-sisa kulit/cangkang atau benda asing yang masih bercampur dengan daging rajungan, pengecekan dilakukan secara sederhana dengan pengamatan dan perabaan, namun pengecekan tidak semua dilakukan. Pengemasan dalam toples plastik dan dilakukan untuk daging dengan jenis yang berbeda, daging tidak diisi secara penuh dalam toples untuk kesempurnaan pendinginan selama penyimpanan, namun hal ini juga dapat mempercepat proses pembusukan dikarenakan proses pengupasan yang memakan waktu relatif lama.

Tabel3. Data hasil wawancara dan observasi pada 7 miniplant

\begin{tabular}{|c|c|c|c|c|c|c|c|c|}
\hline \multirow{2}{*}{$\begin{array}{c}\text { Alur } \\
\text { Proses }\end{array}$} & \multirow{2}{*}{$\begin{array}{l}\text { Kri- } \\
\text { teria }\end{array}$} & \multicolumn{7}{|c|}{ Miniplant/ Penilaian/ (\%) } \\
\hline & & M1 & M2 & M3 & M4 & M5 & M6 & M7 \\
\hline $\begin{array}{l}\text { Peneri } \\
\text { maan } \\
\text { Bahan } \\
\text { Baku }\end{array}$ & $S$ & 100 & 100 & 100 & 100 & 100 & 100 & 100 \\
\hline \multirow{2}{*}{$\begin{array}{l}\text { Sortasi } \\
\text { Bahan } \\
\text { Baku }\end{array}$} & $\mathrm{S}$ & 66,7 & 66,7 & 66,7 & 66,7 & 66,7 & 100 & 66,7 \\
\hline & $\mathrm{KS}$ & 33,3 & 33,3 & 33,3 & 33,3 & 33,3 & & 33,3 \\
\hline \multirow{2}{*}{$\begin{array}{l}\text { Perebu } \\
\text { san }\end{array}$} & $\mathrm{S}$ & 80 & 80 & 80 & 80 & 80 & 80 & 60 \\
\hline & $\mathrm{KS}$ & 20 & 20 & 20 & 20 & 20 & 20 & 40 \\
\hline \multirow{3}{*}{$\begin{array}{l}\text { Pengup } \\
\text { asan }\end{array}$} & $\mathrm{S}$ & 44,4 & 44,4 & 55,6 & 55,6 & 44,4 & 55,6 & 44,5 \\
\hline & $\mathrm{KS}$ & 55,6 & 55,6 & 44,4 & 44,4 & 55,6 & 44,4 & 44,5 \\
\hline & TS & & & & & & & 11 \\
\hline \multirow{2}{*}{$\begin{array}{l}\text { Pengec } \\
\text { ekan } \\
\text { Akhir }\end{array}$} & $\mathrm{S}$ & 50 & 50 & 50 & 50 & 50 & 50 & 50 \\
\hline & $\mathrm{KS}$ & 50 & 50 & 50 & 50 & 50 & 50 & 50 \\
\hline \multirow{2}{*}{$\begin{array}{l}\text { Penge } \\
\text { masan }\end{array}$} & $\mathrm{S}$ & 33,3 & 33,3 & 33,3 & 33,3 & 33,3 & 33,3 & 33,3 \\
\hline & $\mathrm{KS}$ & 66,7 & 66,7 & 66,7 & 66,7 & 66,7 & 66,7 & 66,7 \\
\hline \multirow{2}{*}{$\begin{array}{l}\text { Penyim } \\
\text { panan }\end{array}$} & $\mathrm{S}$ & 100 & 100 & 100 & 100 & 100 & 100 & \\
\hline & $\mathrm{KS}$ & & & & & & & 100 \\
\hline \multirow{2}{*}{$\begin{array}{l}\text { Penyet } \\
\text { oran ke } \\
\text { Pabrik }\end{array}$} & $\mathrm{S}$ & 50 & 50 & 50 & 50 & 50 & 50 & 50 \\
\hline & $\mathrm{KS}$ & 50 & 50 & 50 & 50 & 50 & 50 & 50 \\
\hline
\end{tabular}

Hasil penelitian penerapan GMP (Good Manufacturing Practice) dari 7 miniplant pada Tabel 4 menunjukkan nilai yang terbaik pada M6 (Miniplant UD Barokah) sebesar 71\% sesuai, 29\% kurang sesuai, dan nilai yang terendah pada M7 (Miniplant bapak Rudi) sebesar $58 \%$ sesuai, $31 \%$ kurang sesuai, dan $11 \%$ tidak sesuai

\section{Nilai Organoleptik Daging rajungan}

Penilaian organoleptik merupakan penilaian menggunakan panca indera pengamat untuk menilai faktor-faktor mutu yang umumnya dikelompokkan atas penampakan, bau, cita rasa, tekstur.Organoleptik dapat menggambarkan kemunduran mutu suatu produk perikanan. Tabel .. menyajikan rata-rata nilai organoleptik daging rajungan pada tahapan proses penanganan di mini plant

Tabel 4. Data hasil uji organoleptik

\begin{tabular}{llc}
\hline No & \multicolumn{1}{c}{$\begin{array}{c}\text { Tahapan proses } \\
\text { penanganan }\end{array}$} & $\begin{array}{c}\text { Nilai } \\
\text { Organoleptik }\end{array}$ \\
\hline 1. & (daging segar) & 8,9 \\
2. & (daging matang) & 7,9 \\
\hline
\end{tabular}

Pada penilaian organoleptik daging rajungan rebus digunakan score sheet penilaian sensori daging rajungan. Kriteria pengujian sensori meliputi penampakan, bau dan tekstur. Penampakan diukur dari segi ada tidaknya pengotor, warna diukur dari cemerlang atau kusam, sedangkan bau (aroma) diukur dari ketajarnan clan kesegaran bau khas rajungan. 
Pada penilaian organoleptik cukup manis)

daging rajungan digunakan score sheet penilaian sensori daging rajungan. Kriteria pengujian sensori meliputi penampakan, bau, dan tekstur. Proses penurunan mutu daging rajungan disebabkan oleh kegiatan mikroorganisme yang menjadi kontaminan pada produk daging rajungan. Aktivitas mikroba dapat menguraikan komponen daging rajungan, sehingga menyebabkan rusaknya struktur jaringan rajungan dan teksturnya menjadi lebih lunak selain itu, hasil penguraian senyawa mikromolekul pada daging seperti asam amino bebas, asam laktat, gula pereduksi akan menghasilkan metabolit penyebab bau busuk.

Berdasarkan pengujian organoleptik diketahui karateristik nilai oragnoleptik daging rajungan industri rumah tangga berada pada nilai diatas 7 . Hal ini berarti bahwa daging rajungan tersebut memenuhi spesifikasi persyaratan mutu daging rajungan rebus dingin berdasarkan SNI 4224:2015. Nilai skor sensori minimum berdasarkan standart yang harus dicapai rajungan matang hasil perebusan adalah nilai 6 (tekstur agak padat, kurang kompak, bau, kurang tajam, dan agak segar, penampakan sedikit kusam dan kurang cemerlang, ada serpihan sel dan rasanya

\section{Nilai TPC Daging Rajungan}

Nilai total bakteri (Total Plate Count) adalah menggambarkan kemunduran mutu secara mikrobiologis dari suatu produk. Tabel .. menunjukkan rata-rata total nilai bakteri pada-setiap tahapan penanganan rajungan sampai menjadi produk daging rajungan rebus

Tabel 5. Data hasil uji TPC

\begin{tabular}{ccc}
\hline No & $\begin{array}{c}\text { Tahapan proses } \\
\text { penanganan }\end{array}$ & Nilai TPC \\
\hline 1. & (daging segar) & $2,6 \times 10^{4}$ \\
2. & (daging matang) & $3,7 \times 10^{5}$ \\
\hline
\end{tabular}

Secara umum dari Tabel dapat dilihat bahwa nilai TPC mengalami peningkatan pada tiap tahap penanganan. Pada daging rajungan mentah setelah penangkapan didapatkan nilai rata-rata TPC sebesar 2,6 X $10^{4}$ koloni/gram. Tumbuhnya bakteri pada tangkapan rajungan segar mencerminkan keadaan lingkungan hidup rajungan menunjukkan kualitas dan kuantitas yang berbeda tergantung akan musim, kualitas, lokasi geografis.

Nilai TPC daging rajungan matang setelah proses pengambilan daging (picking) di industri rumah tangga adalah sebesar $3,7 \times 10^{5}$ koloni/g. Pada daging rajungan yang telah diolah dengan pemanasan, seharusnya jwnlah bakteri menurun. Perebusan merupakan suatu proses pengawetan yaitu untuk mencegah 
autolisis, dan juga dapat mematikan beberapa jenis mikroorganisme (Gaman dan Sherrington 1992). Jumlah total bakteri pada daging rajungan matang yang makin meningkat diduga disebabkan oleh rekontaminasi selama proses pengolahan dan penanganan di industri rumah tangga.Tahapan proses penanganan yang paling dominan menyebabkan rekontaminasi yaitu pengupasan (picking) selama 2-3 Jam.

Berdasarkan rata-rata nilai total bakteri daging rajungan diketahui bahwa secara mikrobiologis daging rajungan yang diolah di mini plant memenuhi persyaratan spesifikasi persyataran mutu daging rajungan rebus dingin berdasarkan SNI 4224:2015 yaitu memil iki nilai rata-rata total bakteri di bawah maksimum (5 X $10^{5}$ koloni $\left./ \mathrm{g}\right)$.

\section{KESIMPULAN}

Kesesuaian penerapan GMP (Good Manufacturing Practice) pada pengupasan rajungan meliputi alur proses : penerimaan bahan baku, sortasi, perebusan, dan penyimpanan. Bahan baku segar diperoleh langsung dari hasil melaut, suhu dan waktu perebusan sudah sesuai standard yang ditentukan oleh pabrik pengalengan daging rajungan, serta penyimpanan produk sebelum penyetoran bersuhu dibawah $4^{\circ} \mathrm{C}$. Daging rajungan yang dihasilkan di mini plant rajungan telah memenuhi standar SNI 4224:2015 dari segi organoleptik dan mikrobiologis, dengan nilai TPC sebesar $3,7 \times 10^{5}$ koloni/gram dan nilai rata-rata organoleptik sebesar 7,9.

\section{DAFTAR PUSTAKA}

Annonim. 2007. Pedoman Penilaian Kelayakan Dasar Unit Pengolahan Ikan . Jakarta. Departemen Kelautan dan Perikanan.

Annonim. 2015. Laporan Tahunan. Dinas Perikanan dan Kelautan Kabupaten Tuban. Tuban.

Priyanti. 2007. Pengamatan Proses Pengolahan Daging Rajungan (Portunus pelagicus Linn) Kaleng Di PT Mina Global Mandiri. Laporan Praktek Integrasi. Jakarta. Jurusan Tehnologi Pengolahan Hasil Perikanan Sekolah Tinggi Perikanan.

Purwaningsih,S., Josephine W, dan Diana Sri Lestari. 2005. Pengaruh Lama Penyimpanan Daging Rajungan (Portunus pelagicus) Rebus Pada Suhu Kamar. Buletin Teknologi Hasil Perikanan. Volume VIII Nomor 1. Bogor. Departemen Teknologi Hasil Perairan FPIKIPB.

Satumalay, 2012. Manajemen Mutu Pengolahan Kepiting Rajungan (Portunus Pelagicus) Pada Beberapa Mini Plant Di Kabupaten Maros. Thesis. Makasar. Universitas Hassanudin.

Sugeng, Sapto P.R., Subiyanto, dan Hadi P., 2003., Budidaya Rajungan 
(Portunus pelagicus) di

Tambak. Jepara. BBPBAP

Jepara.

Sunarto. 2011. Karakteristik Bioekologi Rajungan (Portunus pelagicus) di Perairan Laut Kabupaten Brebes. Disertasi. Bogor. Sekolah Pascasarjana - Institut Pertanian Bogor.

Widhiastuti. 2010. Analisis Rantai Pasokan Rajungan, Stusi Kasus PT Windika Utama Semarang Jawa Tengah. Skripsi. Bogor. Departemen Tehnologi Hasil Perairan. Fakultas Perikanan dan Ilmu Kelautan IPB. 